\title{
Coğrafya Öğretmen Adaylarının Öğretmenlik Mesleğine Yönelik Tutum ve Kaygı Düzeyleri (Erzurum Örneği)
}

\author{
Yllmaz KESKIN \\ Atatürk Üniversitesi, Kazım Karabekir Eğitim Fakültesi, Coğrafya Ĕgitimi ABD, Erzurum \\ e-posta: yilmazkskn@gmail.com
}

\begin{abstract}
$\ddot{O}_{z e t}$
Bu araştırma Coğrafya öğretmen adaylarının öğretmenlik mesleğine yönelik tutum ve kaygı düzeylerini belirlemek amacıyla hazırlanmıştır. Çalışma grubunu 2015-2016 eğitim öğretim yılında Atatürk Üniversitesi Coğrafya Öğretmenliği Anabilim Dalında öğrenim gören 35 öğrenci ve yine aynı dönemde coğrafya öğretmenliği pedegojik formasyon sertifikası programında yer alan 45 öğrenci olmak üzere toplam 80 öğrenci oluşturmuş̧tur. Nicel araştırma yöntemlerinden betimsel tarama modelinin kullanıldığı araştırma verileri SPSS programı kullanılarak frekans ve yüzdeler hesaplanmış, bağımsız örneklem t testi, tek yönlü varyans analizi (ANOVA) ve Scheffe testi yapılmıştır.

Çalışmadan elde edilen verilere göre öğretmen adaylarının öğretmenlik mesleğine yönelik tutum düzeylerinin yüksek, kaygı düzeylerinin orta seviyede olduğu belirlenmiştir. Öğretmen adaylarının öğretmenlik mesleğine yönelik tutumları fakülteleri ve cinsiyetlerine göre değişmezken, AGNO'ları ve okudukları bölümü tercih nedenlerine göre değişmektedir. Ayrıca öğretmen adaylarının öğretmenlik mesleğine yönelik kaygı düzeyleri fakülte, cinsiyet, AGNO ve okudukları bölümleri tercih nedenlerine göre değişiklik göstermemektedir.
\end{abstract}

Anahtar Kelimeler: Coğrafya, Öğretmen adayı, Öğretmen yetiştirme, tutum, kaygı

\section{Attitude and Concern Levels of Geography Teacher Candidates Towards The Profession of Teaching (Erzurum Example)}

\begin{abstract}
This research is intended to determine the attitude and concern levels of geography teacher candidates towards the profession of teaching. The study group is comprised of 80 students, being 35 students from the Department of Geography Teaching of Ataturk University in 2015-2016 academic year and 45 students attending to the pedagogical formation certificate program in the same academic year. The research data have been collected by means of descriptive survey model, being a quantitative research method, and the frequency and percentage of such data have been calculated with SPSS software, whereas unpaired t test, one-way analysis of variance (ANOVA) and Scheffe tests have been performed.

According to the data obtained from the study, it is established that the attitude level of teacher candidates towards the profession of teaching is high and their concern level is moderate. The attitudes of teacher candidates towards the profession of teaching do not vary depending on their faculties and genders, however they vary depending on their CGPA's and their reasons for choosing their branches. Besides the concern levels of teacher candidates towards the profession of teaching do not vary depending on their faculties, genders, CGPA's and branches.
\end{abstract}

Keywords: Geography, Teacher candidate, Teacher training, attitude, concern

\section{GİRiş}

Sağlıklı bir toplum oluşturmanın en önemli yapı taşı eğitim sistemi ve onun etkin bir şekildeki işlerliğidir. Herkes tarafindan öğretmenin bu sistemin temel öğesi olup, diğer öğelere göre de etkileme gücünün fazla olduğu bilinmektedir (Çapa \& Çil, 2000). Öğretmenlik mesleği, sabırlı olmayı ve özverili çalışmayı, sürekli kendini geliştirmeyi gerektiren önemli bir meslektir. Öğretmenlik mesleğinde başarı bu mesleği sevmekle sağlanabilir (Sağlam, 2008). Pek çok eğitimcinin hemfikir olduğu nokta bireyin başarıya ulaşmasının tutumlarıyla ilişkili olduğudur (Zaman \& Coşkun, 2007). Bireyin yaşamı tercih ettiği meslekle şekillenir. Bireylerin kendilerine uygun meslekler seçmesi, mesleklerine karşı tutumlarının olumlu olması sağlar. Bu da sadece kendilerini mutlu etmekle kalmayıp toplumun kalkınmasında da ciddi katkılar yapmalarını sağlar (Bozdoğan, Aydın, \& Yıldırım, 2007).

Nitelikli öğretmen yetiştirmenin ilk adımı öğretmen adaylarının seçiminde öğretmenlik mesleğini seven ve isteyen adayların seçilmesi olmalıdır (Özder, Konedralı, \& Zeki, 2010). Çünkü öğretmenler tutumlarıyla öğrencilerini etkilerler. Bu yüzden tutum önemlidir (Tufan \& Güdek, 2008). Tutum ile ilgili pek çok tanımlama yapılmış olmakla birlikte tutumu, "bir bireye atfedilen ve onun bir psikolojik obje ile ilgili düşünce, duygu ve davranışlarını düzenli bir biçimde oluşturan bir eğilimdir” şeklinde tanımlamak mümkündür (Pehlivan, 2008). Öğretmenlerin mesleklerine yönelik tutumları ve alışkanlıkları; mesleklerini sevmeleri, mesleklerine bağlı olmaları, mesleklerinin önemli olduğunun bilinç ve sorumluluğunda olmaları, mesleklerinde kendilerini sürekli geliştirmeleri ile ilgilidir. Olumlu ya da olumsuz tutumlar, öğretmen adaylarının mesleki davranışlarını 
yönlendirmede oldukça belirleyicidir (Özkan, 2012). Öğretmen adaylarının ve mensuplarının kendilerini yenileyebilmeleri için araştırmacı olmaları, mesleklerini sevmeleri ve öğretmenlik mesleğine karşı olumlu tutum geliştirmeleri gerekmektedir (Kaplan \& İpek, 2002). Öğretmenlik mesleğine yönelik olumlu tutumun gelişebilmesi içinde öncelikle mesleğe karşı sevgi ve istek duyulması gerekmektedir (Tunçeli, 2013). Mesleğe yönelik olumlu tutum beraberinde başarıyı ve yaşam doyumunu da getirecektir (Recepoğlu, 2013).

Öğretmenlik mesleğine adım atan öğretmen adaylarının öğretmenlik mesleğine yönelik olumlu tutum ve değerler kazanmaları, olumlu algılara sahip olmaları, meslek yaşamlarındaki başarılarının belirleyicisi olacaktır (Karadağ, 2012). Öğretmen adaylarının öğretmenlik mesleğine ilişkin tutumları onların gelecekte üyesi olacakları öğretmenlik mesleğini nasıl yerine getireceklerinin emarelerini taşır. Birey mesleğine karşı olumlu bir tutuma sahip olduğu sürece mesleğini de daha iyi yapma eğiliminde olacaktır. Mesleğe karşı olumlu tutum öğretmenin sınıf içi davranışlarına yansıyacak ve rolünü daha iyi yerine getirmesini sağlayacaktır (Recepoğlu, 2013).

Öğretmenlerin mesleğe yönelik olumlu tutum geliştirmeleri, günümüzde öğretmen yetiştirme programlarının önemli amaçları arasında görülmektedir (Başbay, Ünver, \& Bümen, 2009). Öğretmenlik mesleğine ilişkin problemler düşünüldüğünde, öğretmenlerin kendilerinden beklenen rolleri yerine getirmelerini etkileyen önemli bir unsurun, mesleği sevme, saygı duyma ve benimseme özelliklerini kapsayan tutumları üzerinde durmak gerekli görülmektedir (Pehlivan, 2008). Öğretmen adaylarının öğretmenlik mesleğine yönelik tutumları ve icra edecekleri mesleğe ilişkin kaygı düzeyleri yetiştirilen öğretmen adaylarının kalitesinde önemli bir yer tutmaktadır (Serin, Güneş, \& Değirmenci, 2015). Öğretmen adaylarına sunulacak nitelikli bir eğitim ortamı onlara öğretmenlik mesleğinin gereklerini yerine getirebilmeleri için yeterlilik kazandırmalıdır. Öğretmen adaylarına verilen eğitim, alanlarına ilişkin bilgi ve becerileri kazandırırken, öğretmen adaylarııı mesleğe yönelik tutumları ve kaygıları da dikkate alınmalıdır. (Aydın \& Tekneci, 2013).

Öğretmen adaylarının meslekle ilgili kaygıları mezuniyet aşamasında, atanma, kpss sınavı veya iş bulma kaygılarıyla doruk noktasına ulaşır (Atmaca, 2013). Bu kaygıların farklı kaynakları bulunmaktadır. Benmerkezli kaygıların odak noktası bireyin kendisidir. Ben-merkezli kaygıları taşıyan öğretmen adayı, öğretmenlik mesleğini başarıp başaramayacağı endişesini taşır ve bu nedenle sürekli olarak tedirginlik yaşar. Bu durumdaki bir öğretmen adayı daima şu soruları kendisine sorar: 1) Acaba öğretmenlik mesleği bana göre mi? 2) Acaba öğretmenlik mesleğini her gün nasıl yapacağım? 3) Acaba veliler öğretmenliğim bakımından beni yeterli görecekler mi? Görev merkezli kaygılar bireyin öğretmenlik mesleği ile alakalıdır. Görev-merkezli kaygıları taşıyan bir öğretmen adayı, iyi bir öğretmen olabilme kaygısını taşır ve bu sebeple alanında meydana gelen yenilikleri, yeni öğretim yöntemlerini, yeni öğretim araç-gereçlerini yakından takip eder. Böyle durumdaki bir öğretmen adayı kendisine sürekli şu soruları yöneltir: 1) Acaba her gün çok sayıda öğrenciyle başa çıkabilecek miyim? 2) Acaba öğretim konusunda yeni yöntemleri, yeni teknikleri, yeni materyalleri nasıl elde edebilirim? 3) Acaba öğretmenden beklenen çok sayıda görevi yerine getirebilecek miyim? Öğrenci-merkezli kaygıların odak noktası ise öğrencilerdir. Öğrenci-merkezli kaygıları yaşayan bir öğretmen adayı daha çok öğrenci merkezli düşünür ve her bir öğrencinin fiziksel, zihinsel, duygusal veya sosyal ihtiyaçlarını nasıl karşllayacağının endişesini taşır ve kendisini bu alanda yoğunlaştırır. Bu durumdaki bir öğretmen adayı kendisine sürekli şu soruları sorar: 1) Acaba her öğrenciye nasıl yardım edebilirim ki daha kolay ve daha çabuk öğrenme gerçekleşsin? 2) Acaba her öğrenciye nasıl yardım edebilirim ki öğrenciler kendilerine güven ve başarı duygularını geliştirsin? 3) Acaba her bir öğrenciye nasıl yardım edebilirim ki kendi potansiyelini keşfetsin ve geliştirsin? (Saban, Korkmaz, \& Akbaşl1, 2004, p. 198).

Orta düzeydeki kaygının organizmayı uyarıcı, koruyucu ve motive edici özelliği vardır. Kaygı iyi yönetildiğinde bireyin başarılı olmak için daha fazla çalışmasına, yaşanacak olumsuzluklara karşı önlem almasına yardımcı olmaktadır. Bu nedenle özellikle öğretmen adaylarının mesleğe yönelik kaygı düzeylerinin orta seviyede tutulması, ileride meslek yaşantılarına yönelik olumlu tutum geliştirmelerine, geliştirilen bu olumlu tutumların da mesleklerini severek yapmalarına ve daha başarılı olmalarına yardımı olacaktır (Varol, Erbaş, \& Ünlü, 2014).

Coğrafya öğretmen adaylarının, mesleklerine başladıklarında başarılı olabilmelerinin belirleyicilerinden iki tanesi mesleğe yönelik tutum ve kaygı düzeyleridir. Mesleğini sevmeyen, olumlu tutum geliştirmeyen öğretmenler, karışılacakları zorlukları başarısızlıkların bahanesi olarak gösterirken, mesleğini severek yapan ve olumlu tutum geliştiren öğretmenler ise karşılaşacakları güçlükleri aşmak için mücadele vereceklerdir. Öğretmen adaylarının mesleğe yönelik kaygı düzeyleri ne çok yüksek ne de çok düşük olması beklenmektedir. Çünkü öğretmen adaylarının mesleğe yönelik kaygısının olmaması onların mesleği önemsemediğini gösterebilir. Yine aşırı düzeyde kaygılanan öğretmen adayları ise kaygıları mesleklerini yapmalarının önüne geçebilir ve başarısız olabilirler. $\mathrm{O}$ yüzden geleceğin öğretmenleri olan öğretmen adaylarının iyi bir öğretmen olabilmeleri için mesleğe yönelik orta düzeyde kaygılara sahip olmaları ve olumlu tutum geliştirmeleri gerekir.

Günümüzde Millî Eğitim Bakanlığının ihtiyacı olan coğrafya öğretmenleri iki farklı kaynaktan yetiştirilmektedir. Bunlardan birisini Eğitim Fakültelerinin coğrafya öğretmenliği anabilim dalı mezunları oluştururken diğerini edebiyat fakültelerinin coğrafya bölümü mezunlarından pedagojik formasyon eğitimi sertifikasını alabilenler oluşturmaktadır. Yapılan literatür taramasında farklı branşlardaki öğretmen adaylarının 
öğretmenlik mesleğine yönelik tutum ve kaygılarıyla ilgili pek çok çalışma bulunurken coğrafya öğretmen adaylarıyla ilgili olarak Alım ve Bekdemir'in (2006) öğretmen adaylarının tutumları ve Ünaldı ve Alaz'n (2008) öğretmen adaylarının kaygılarıyla ilgili yapılan çalışmalar dışında çalışmalara rastlanmamıştır. Bu çalışma bu alana katkı sağlayabilmek adına iki farklı kaynaktan beslenen öğretmen adaylarının öğretmenlik mesleğine yönelik tutum ve kaygılarını belirlemek amacıyla gerçekleştirilmiştir.

$\mathrm{Bu}$ araştırmada edebiyat fakültesi coğrafya bölümünde öğrenim görüp pedagojik formasyon alan coğrafya öğretmen adayları ve eğitim fakültesi coğrafya eğitimi bölümünde öğrenim gören coğrafya öğretmen adaylarının öğretmenlik mesleğine yönelik tutum ve kaygı düzeyleri bazı değişkenlere göre ortaya konmaya çalışılmıştır. Bu temel amaç çerçevesinde aşağıdaki sorulara cevap aranmıştır:

1. Coğrafya öğretmen adaylarının öğretmenlik mesleğine yönelik tutum ve kaygı düzeyleri nasıldır?

2. Coğrafya öğretmen adaylarını öğretmenlik mesleğine yönelik tutum ve kaygı düzeylerinde fakültelere, cinsiyete, AGNO'larına ve okudukları bölümü tercih etme nedenlerine göre anlamlı farklılık var mıdır?

\section{YÖNTEM}

\section{Araştırma Modeli}

Bu çalışma, coğrafya öğretmen adaylarının öğretmenlik mesleğine yönelik tutum ve kaygı düzeylerini belirlemek amacıyla yapıldığı için tarama modelinde betimsel desenli bir araştırmadır. Bir grubun belirli özelliklerini belirlemek için verilerin toplanmasını amaçlayan çalışmalara tarama (survey) araştırması denir (Büyüköztürk, Çakmak, Akgün, Karadeniz, \& Demirel, 2012, p. 14).

\section{Çalışma Grubu}

Bu araştırmanın çalışma grubunu 2015-2016 Eğitim-Öğretim yılı Bahar döneminde Atatürk Üniversitesi Kazım Karabekir Eğitim Fakültesi Coğrafya Eğitimi Anabilim Dalında pedagojik formasyon alan 45 (\% 56,3) öğretmen adayı ve aynı fakültenin son sınıf öğrencileri olan 35 (\% 43,7) öğretmen adayı olmak üzere toplam 80 öğretmen adayı oluşturmaktadır. Ayrıca çalışma grubunun cinsiyete göre dağılımına bakıldığında ise \% 43,7'si (35 kişi) kadınlardan, \% 56,3'ü (45 kişi) ise erkeklerden oluşmaktadır. Çalışma grubunun cinsiyet ve fakültelere ilişkin dağılımı tablo 1 'de verilmiştir.

Tablo 1

Çalışma grubunun fakülte ve cinsiyetlere ilişkin dağılımı

\begin{tabular}{lcccccc}
\hline & \multicolumn{2}{c}{ Eğitim Fakültesi } & \multicolumn{2}{c}{ Edebiyat Fakültesi } & \multicolumn{2}{c}{ Toplam } \\
\hline Cinsivet & F & \% & F & \% & F & \% \\
\hline Kadın & 12 & 34,3 & 23 & 51,1 & 35 & 43,7 \\
\hline Erkek & 23 & 65,7 & 22 & 48,9 & 45 & 56,3 \\
\hline TOPLAM & 35 & 100 & 45 & 100 & 80 & 100 \\
\hline \hline
\end{tabular}

Çalışma grubun AGNO'larına ilişkin dağılıma bakıldığında büyük çoğunluğunun (\% 63,7) 3,00 ile 3,49 arasında not ortalamasına sahip oldukları görülmektedir. Bu oranın fazla olmasındaki temel etken öğrencilerin pedagojik formasyon alabilmesi için not ortalamasının yüksek olmasının gerekmesindendir. Dolayısıyla pedagojik formasyon alan öğrencilerin \% 84,4'ü 3,00 ile 3,49 arasında not ortalamasına sahip öğrencilerden oluşmaktadır. $\mathrm{Bu}$ da genele yansımış ve çalışma grubunun \% 63,7'si 3,00-3,49 not ortalamasına sahip öğrencilerden oluşmuştur. Çalışma grubunun fakültelere göre AGNO'larına ilişkin dağılımı tablo 2 'te verilmiştir.

Tablo 2.

Çalışma gurubunun AGNO'larına ilişskin dağıllımı

\begin{tabular}{lcccccc}
\hline & \multicolumn{2}{c}{ Eğitim Fakültesi } & \multicolumn{2}{c}{ Edebiyat Fakültesi } & \multicolumn{2}{c}{ Toplam } \\
\hline AGNO & F & $\mathbf{\%}$ & F & \% & F & \% \\
\hline $2,00-2,49$ & 2 & 5,7 & 0 & 0 & 2 & 2,5 \\
\hline $2,50-2,99$ & 18 & 51,4 & 7 & 15,6 & 25 & 31,3 \\
\hline $3,00-3,49$ & 13 & 37,1 & 38 & 84,4 & 51 & 63,7 \\
\hline $3,50-4,00$ & 2 & 5,7 & 0 & 0 & 2 & 2,5 \\
\hline TOPLAM & 35 & 100 & 45 & 100 & 80 & 100 \\
\hline
\end{tabular}

Çalışma grubunun öğrenim gördükleri bölümü tercih etme nedenlerine ilişkin dağılıma bakıldığında "Coğrafyaya karşı olan ilgim” (\% 33,8), "İstediğim meslek olması" (\% 30), "ÖSS-LYS Puanım” (\% 18,8) öne çıkan tercih sebepleridir. Ancak fakültelere göre tercih nedenlerine bakıldığındaysa eğitim fakültesinde öğrenim gören öğretmen adaylarında "İstediğim meslek olması" öne çıkarken edebiyat fakültesinde öğrenim gören öğretmen adaylarında "Coğrafyaya karşı olan ilgim" tercih nedeni olarak öne çıkmaktadır. Çalışma grubunun 
fakültelere göre okudukları bölümü tercih nedenlerine ilişkin dağılımı tablo 3’te verilmiştir.

Tablo 3

Çalışma grubunun öğrenim gördükleri bölümü tercih etme nedenlerine ilişskin dağıllımı

\begin{tabular}{lcccccc}
\hline & \multicolumn{2}{c}{ Eğitim Fakültesi } & \multicolumn{2}{c}{ Edebiyat Fakültesi } & \multicolumn{2}{c}{ Toplam } \\
\hline Tercih Nedeni & $\mathbf{F}$ & $\mathbf{\%}$ & $\mathbf{F}$ & $\mathbf{\%}$ & $\mathbf{F}$ & $\mathbf{\%}$ \\
\hline ÖSS-LYS Puanım & 6 & 17,1 & 9 & 20,0 & 15 & 18,8 \\
\hline İstediğim meslek olmas1 & 12 & 34,3 & 12 & 26,7 & 24 & 30,0 \\
\hline İs garantisi & 5 & 14,3 & 1 & 2,2 & 6 & 7,5 \\
\hline Öğretmenlerin önerisi & 1 & 2,9 & 2 & 4,4 & 3 & 3,8 \\
\hline Anne-baba telkini & 4 & 11,4 & 1 & 2,2 & 5 & 6,3 \\
\hline Coğrafyaya karşı olan ilgim & 7 & 20,0 & 20 & 44,4 & 27 & 33,8 \\
\hline TOPLAM & 35 & 100 & 45 & 100 & 80 & 100 \\
\hline \hline
\end{tabular}

\section{Veri Toplama Araçları}

Çalışmada Üstüner (2006)'in geliştirmiş olduğu "Öğretmenlik Mesleğine Yönelik Tutum Ölçeği” ve Cabi ve Yalçınalp (2013)'in geliştirmiş oldukları "Öğretmen Adaylarına Yönelik Mesleki Kaygı Ölçeği (MKÖ)" kullanılmıştır. Her iki ölçek de 5'li likert tipinde hazırlanmıştır. Öğretmenlik Mesleğine Yönelik Tutum Ölçeği 1=Hiç katılmıyorum, 2= Kısmen Katılıyorum, 3=Orta düzeyde Katılıyorum, 4= Çoğunlukla Katılıyorum, 5=Tamamen Katılıyorum şeklinde, Öğretmen Adaylarına Yönelik Mesleki Kaygı Ölçeği (MKÖ) ise 1=Kaygılanmıyorum, 2=Çok Az Kaygılanıyorum, 3= Kısmen Kaygılanıyorum, 4= Oldukça Kaygılanıyorum, $5=$ Çok Kaygılanıyorum şeklinde derecelendirilmiştir. Üstüner (2006) ölçeğin güvenirlik katsayısını .93 olarak hesaplamıştır. Bu çalışmada ise "Öğretmenlik Mesleğine Yönelik Tutum Ölçeği”nin güvenirlik katsayısı .96 olarak bulunmuştur. Cabi ve Yalçınalp (2013) ise geliştirmiş oldukları ölçeğin güvenirlik katsayısını .95 olarak bulmuşlardır. Bu çalışmada da "Öğretmen Adaylarına Yönelik Mesleki Kaygı Ölçeği (MKÖ)"nin güvenirlik katsayısı .95 olarak hesaplanmıştır. Her iki ölçekten de elde edilen güvenirlik katsayıları Kayış (2010)'a göre ölçeklerin güvenilir olduğunu ortaya koymaktadır.

\section{Veri Analizi}

Öğretmen adaylarının öğretmenlik mesleğine yönelik tutumları ve kaygı düzeylerinin cinsiyete ve öğrenim gördükleri fakültelere göre değişip değişmediğini belirlemek için bağımsız örneklem t-testi, AGNO'ları ve okudukları bölümü tercih nedenlerine göre anlamlı bir farklılık olup olmadığını belirlemek için ise tek yönlü varyans analizi (ANOVA) testi yapılmıştır. ANOVA testi sonucunda ortaya çıkan anlamlı farklıı̆ı̆ın kaynağını bulmak için ise Scheffe testi uygulanmıştır. Analizler SPSS programı kullanılarak yapılmıştır.

\section{BULGULAR}

\section{1. Öğretmen Adaylarının Öğretmenlik Mesleğine Yönelik Tutumlarına İlişkin Bulgular}

Öğretmen adaylarının öğretmenlik mesleğine yönelik tutumlarına ilişkin bulgular tablo 4 'te verilmiştir.

Tablo 4

Öğretmen adaylarının ögretmenlik mesleğine yönelik tutum düzeyleri

\begin{tabular}{llcccc}
\hline & $\mathbf{N}$ & Minimum & Maksimum & $\bar{X}$ & Ss \\
\hline Tutum puanı ortalaması & 80 & 2,09 & 4,94 & 3,97 &, 81 \\
\hline
\end{tabular}

Tablo 4'e bakıldığında öğretmen adaylarının öğretmenlik mesleğine yönelik tutum puanı ortalamalarının 3,97 ve en düşük tutum puanı ortalamasının 2,09, en yüksek tutum puanı ortalamasının ise 4,94 olduğu görülmektedir. Öğretmen adaylarının tutum puanı ortalamalarına bakıldığında öğretmen adaylarının öğretmenlik mesleğine yönelik olumlu tutum geliştirdikleri görülmektedir.

Çalışma grubunun, öğrenim gördükleri fakültelere göre öğretmenlik mesleğine yönelik tutum puanı ortalamalarındaki farklılığın istatistiksel açıdan anlamlı olup olmadığını belirlemek için bağımsız örneklem t testi yapılmış ve sonuçlar tablo 5 'te verilmiştir.

Tablo 5

Öğretmen Adaylarının öğretmenlik mesleğine yönelik tutumlarına yönelik öğrenim görülen fakültelere ilişkin t testi sonuçları

\begin{tabular}{lllllll}
\hline Fakülte & $\mathbf{N}$ & $\bar{X}$ & Ss & Sd & t & p \\
\hline \hline Eğitim Fakültesi & 35 & 3,76 &, 88 & & \\
\hline
\end{tabular}




\begin{tabular}{lllllll}
\hline Edebiyat Fakültesi & 45 & 4,12 &, 73 & 65,482 & $-1,953$ &, 055 \\
\hline
\end{tabular}

Tablo 5'e bakıldığında eğitim fakültesinde öğrenim gören öğretmen adaylarının tutum puanı ortalamaları 3,76, edebiyat fakültesinde öğrenim gören öğretmen adaylarının tutum puanı ortalamalarının 4,12 olduğu görülmektedir. Ancak tutum puanı ortalamaları arasında farklılık istatistiksel olarak anlamlı bulunmamıştır $(\mathrm{t}(65,482)=-1,953, \mathrm{p}>0,05)$. Bu sonuca göre genel olarak öğretmen adayları öğretmenlik mesleğine yönelik olumlu tutum geliştirmekle birlikte bu durum öğrenim görülen fakülteye göre değişmemektedir.

Tablo 6

Öğretmen Adaylarının ögretmenlik mesleğine yönelik tutumlarına yönelik cinsiyete ilişkin t testi sonuçları

\begin{tabular}{lllllll}
\hline Cinsiyet & $\mathbf{N}$ & $\bar{X}$ & Ss & Sd & t & p \\
\hline Kadin & 35 & 4,16 &, 87 & & & \\
Erkek & 45 & 3,81 &, 74 & 1,937 &, 056 \\
\hline
\end{tabular}

Tablo 6'ya göre kadın öğretmen adaylarının öğretmenlik mesleğine ilişkin tutum puanı ortalamaları 4,16, erkek öğretmen adaylarının tutum puanı ortalamaları ise 3,81 olup aradaki farklılık istatistiksel olarak anlamlı bulunmamıştır $(\mathrm{t}(78)=1,937, \mathrm{p}>0,05)$. Elde edilen bulgulara göre öğretmen adayları öğretmenlik mesleğine yönelik olumlu tutum geliştirmektedirler ve bu durum cinsiyete göre değişmemektedir.

Tablo 7

Öğretmen adaylarının AGNOlarına göre ögretmenlik mesleğine yönelik tutum puanı ortalamalarına ilişkin betimsel verileri

\begin{tabular}{lccc}
\hline AGNO & $\mathbf{N}$ & $\overline{\mathbf{X}}$ & Ss \\
\hline \hline $2,00-2,49$ & 2 & 3,04 &, 02 \\
\hline $2,50-2,99$ & 25 & 3,69 &, 84 \\
\hline $3,00-3,49$ & 51 & 4,11 &, 77 \\
\hline $3,50-4,00$ & 2 & 4,63 &, 44 \\
\hline TOPLAM & 80 & 3,97 &, 81 \\
\hline
\end{tabular}

Tablo 7 incelendiğinde öğretmen adaylarının AGNO’larına göre, öğretmenlik mesleğine yönelik geliştirmiş oldukları tutum puanı ortalamaları 4,63 (3,50-4,00) ile 3,04 (2,00-2,49) arasında değişmektedir. Öğretmen adaylarının AGNO’ları arttıkça tutum puanlarının da arttı̆̆ı görülmektedir.

Tablo 8

Öğretmen adaylarının ögrretmenlik mesleğine yönelik tutum puanı ortalamalarının AGNO’larına ilişkin tek yönlü ANOVA sonuçları

\begin{tabular}{|c|c|c|c|c|c|c|}
\hline & KT & Sd & KO & $\mathbf{F}$ & $\mathbf{p}$ & Fark (Scheffe) \\
\hline AGNO & 5,578 & 3 & 1,859 & 3,034 &, 034 & $2,00-2,49$ ile $3,50-$ \\
\hline Hata & 46,578 & 76 & ,613 & & & $4,00 / 2,50-2,99$ ile \\
\hline TOPLAM & 52,156 & 79 & & & & $3,00-3,49$ \\
\hline
\end{tabular}

Tablo 8 incelendiğinde öğretmen adaylarının öğretmenlik mesleğine yönelik tutum puanlarındaki AGNO'larına ilişkin fark istatistiksel açıdan anlamlı bulunmuştur( $\mathrm{F}(3-79)=3,034, \mathrm{p}<0,05)$. Bulunan farklılığın hangi gruplar arasında olduğunu belirlemek için scheffe testi yapılmış ve AGNO'su 2,00-2,49 olan öğretmen adayları ile AGNO'su 3,50-4,00 olan öğretmen adaylarının tutum puanları ortalamaları arasında AGNO'su 3,504,00 olan öğretmen adaylarının tutum puanı ortalamaları lehine, 2,50-2,99 olan öğretmen adayları ile AGNO'su 3,00-3,49 olan öğretmen adaylarının tutum puanı ortalamaları arasında, AGNO'su 3,00-3,49 olan öğretmen adaylarının tutum puanı ortalamaları lehine olduğu tespit edilmiştir. Bulunan bu sonuca göre öğretmen adaylarının AGNO'ları öğretmenlik mesleğine yönelik geliştirdikleri tutum puanı ortalamalarını değiştirmektedir.

Tablo 9

Öğretmen adaylarının okudukları bölümü tercih nedenlerine göre öğretmenlik mesleğine yönelik tutum puanı ortalamalarına ilişkin betimsel verileri

\begin{tabular}{llll}
\hline Okuduğu Bölümü Tercih Nedeni & $\mathbf{N}$ & $\overline{\mathrm{X}}$ & Ss \\
\hline \hline 1-ÖSS-LYS Puanım & 15 & 3,50 &, 76 \\
\hline 2-İstediğim meslek olmas1 & 24 & 4,36 &, 49 \\
\hline
\end{tabular}




\begin{tabular}{lccc}
\hline 3-İş garantisi & 6 & 3,63 & 1,08 \\
\hline 4-Öğretmenlerin önerisi & 3 & 4,17 &, 82 \\
\hline 5-Anne-baba telkini & 5 & 3,14 & 1,09 \\
\hline 6-Coğrafyaya karş1 olan ilgim & 27 & 4,08 &, 77 \\
\hline TOPLAM & 80 & 3,97 &, 81 \\
\hline
\end{tabular}

Tablo 9 doğrultusunda öğretmen adaylarının öğretmenlik mesleğine yönelik tutum puanı ortalamalarının 4,36 (İstediğim meslek olması) ile 3,14 (Anne-baba telkini) arasında değiştiği görülmektedir.

Tablo 10

Öğretmen adaylarının öğretmenlik mesleğine yönelik tutum puanı ortalamalarının okudukları bölümü tercih nedenlerine ilişkin tek yönlü ANOVA sonuçları

\begin{tabular}{|c|c|c|c|c|c|c|}
\hline & KT & Sd & KO & $\mathbf{F}$ & p & Fark (Scheffe) \\
\hline Tercih Nedeni & 11,540 & 5 & 2,308 & 4,205 & ,002 & 1 ile $2,6 / 2$ ile $3,5 /$ \\
\hline Hata & 40,616 & 74 &, 549 & & & 5 ile 6 \\
\hline TOPLAM & 52,156 & 79 & & & & \\
\hline
\end{tabular}

Tablo 10 incelendiğinde öğretmen adaylarının öğretmenlik mesleğine yönelik tutum puanlarındaki okudukları bölümü tercih nedenlerine ilişkin fark istatistiksel açıdan anlamlı bulunmuştur $(\mathrm{F}(5-79)=4,205$, $\mathrm{p}<0,05)$. Bulunan farklılığın hangi gruplar arasında olduğunu belirlemek için scheffe testi yapılmıştır. Öğretmen adaylarının öğretmenlik mesleğine yönelik tutum puanı ortalamalarında tercih nedenlerine göre oluşan farkın ÖSS-LYS puanım ile istediğim meslek olması ve coğrafyaya karşı olan ilgim arasında istediğim meslek olması ve coğrafyaya karşı olan ilgim lehine, istediğim meslek olması ile iş garantisi ve anne-baba telkini arasında istediğim meslek olması lehine, anne-baba telkini ile coğrafyaya karşı olan ilgim arasında coğrafyaya karşı olan ilgim lehine olduğu belirlenmiştir. Bulunan bu sonuca göre öğretmen adaylarının okudukları bölümü tercih etme nedenleri öğretmenlik mesleğine yönelik tutumlarını değiştirmektedir.

\section{2. Ö̆̆rretmen Adaylarının Öğretmenlik Mesleğine Yönelik Kaygıları}

Öğretmen adaylarının öğretmenlik mesleğine yönelik kaygıları görev merkezli kaygı, ekonomik/ sosyal merkezli kaygı, öğrenci/ iletişim merkezli kaygı, meslektaş ve veli merkezli kaygı, kişisel gelişim merkezli kayg1, atanma merkezli kaygı, uyum merkezli kayg1, okul yönetimi merkezli kaygı olmak üzere 8 boyut ve genel ortalama kaygı olarak ele alınıp incelenmiştir.

Tablo 11

Öğretmen adaylarının ögretmenlik mesleğine ilişkin kaygı düzeyleri

\begin{tabular}{llcccc}
\hline & N & Minimum & Maksimum & $\bar{X}$ & Ss \\
\hline Görev Merkezli Kayg1 & 80 & 1,00 & 5,00 & 2,29 &, 86 \\
\hline Ekonomik/ Sosyal Merkezli Kayg1 & 80 & 1,00 & 4,71 & 2,67 &, 90 \\
\hline Öğrenci/ İletişim Merkezli Kaygı & 80 & 1,00 & 5,00 & 2,28 & 1,02 \\
\hline Meslektaş ve Veli Merkezli Kayg1 & 80 & 1,00 & 4,20 & 2,19 &, 94 \\
\hline Kişisel Gelişim Merkezli Kayg1 & 80 & 1,00 & 5,00 & 2,20 & 1,24 \\
\hline Atanma Merkezli Kayg1 & 80 & 1,00 & 5,00 & 3,30 & 1,35 \\
\hline Uyum Merkezli Kayg1 & 80 & 1,00 & 5,00 & 2,32 & 1,10 \\
\hline Okul Yönetimi Merkezli Kayg1 & 80 & 1,00 & 5,00 & 2,58 & 1,12 \\
\hline Genel Ortalama Kayg1 & 80 & 1,11 & 3,89 & 2,42 &, 73 \\
\hline
\end{tabular}

Tablo 11 incelendiğinde görev merkezli kaygı düzeylerinin 1,00-5,00 arasında değişip ortalamasının 2,29, ekonomik/ sosyal merkezli kaygl düzeylerinin 1,00-4,71 arasında değișip ortalamasının 2,67, ögrencil iletişim merkezli kaygı düzeylerinin 1,00-5,00 arasında değişip ortalamasının 2,28, meslektaş ve veli merkezli kaygı düzeylerinin 1,00-4,20 arasında değişsip ortalamasının 2,19, kişisel gelişim merkezli kaygı düzeylerinin 1,00-5,00 arasında değişip ortalamasının 2,20, atanma merkezli kaygı düzeylerinin 1,00-5,00 arasında değişip ortalamasının 3,30, uyum merkezli kaygı düzeylerinin 1,00-5,00 arasında değişip ortalamasının 2,32, okul yönetimi merkezli kaygı düzeylerinin 1,00-5,00 arasında değişip ortalamasının 2,58, genel ortalama kaygl düzeylerinin 1,11-3,89 arasında değişip ortalamasının 2,42 olduğu görülmektedir. Öğretmen adaylarının kayg1 düzeyleri ortalamasına bakıldığında en fazla kaygı duydukları konuların atanma merkezli kaygılar olduğu görülmektedir. Ayrıca öğretmen adaylarının kaygı düzeylerinin en düşük olduğu konu da meslektaş/ veli merkezli kaygılardır. 
Tablo 12

Öğretmen Adaylarının öğretmenlik mesleğiyle ilgili kaygılarına yönelik fakülteye ilişkin t testi sonuçları

\begin{tabular}{|c|c|c|c|c|c|c|c|}
\hline & $\underline{\text { Fakülte }}$ & $\mathbf{N}$ & $\bar{X}$ & Ss & Sd & $\mathbf{t}$ & $\mathbf{p}$ \\
\hline \multirow{2}{*}{ Görev Merkezli Kaygı } & Eğitim Fakültesi & 35 & 2,37 & ,95 & \multirow[b]{2}{*}{78} & \multirow[b]{2}{*}{, 716} & \multirow[b]{2}{*}{,476 } \\
\hline & Edebiyat Fakültesi & 45 & 2,23 & ,79 & & & \\
\hline \multirow{2}{*}{$\begin{array}{l}\text { Ekonomik/ Sosyal } \\
\text { Merkezli Kayg1 }\end{array}$} & Eğitim Fakültesi & 35 & 2,62 & 1,00 & \multirow[b]{2}{*}{78} & \multirow[b]{2}{*}{,- 392} & \multirow[b]{2}{*}{,696 } \\
\hline & Edebiyat Fakültesi & 45 & 2,70 &, 82 & & & \\
\hline \multirow{2}{*}{$\begin{array}{l}\text { Öğrenci/ İletişim } \\
\text { Merkezli Kaygı }\end{array}$} & Eğitim Fakültesi & 35 & 2,47 & 1,02 & \multirow[b]{2}{*}{78} & \multirow[b]{2}{*}{1,516} & \multirow[b]{2}{*}{, 134} \\
\hline & Edebiyat Fakültesi & 45 & 2,13 & 1,00 & & & \\
\hline \multirow{2}{*}{$\begin{array}{l}\text { Meslektaş ve Veli } \\
\text { Merkezli Kaygı }\end{array}$} & Eğitim Fakültesi & 35 & 2,33 & 1,07 & \multirow[b]{2}{*}{78} & \multirow[b]{2}{*}{1,195} & \multirow[b]{2}{*}{,236 } \\
\hline & Edebiyat Fakültesi & 45 & 2,08 & ,81 & & & \\
\hline \multirow{2}{*}{$\begin{array}{l}\text { Kişisel Gelişim } \\
\text { Merkezli Kaygı }\end{array}$} & Eğitim Fakültesi & 35 & 2,23 & 1,19 & \multirow[b]{2}{*}{78} & \multirow[b]{2}{*}{, 161} & \multirow[b]{2}{*}{, 873} \\
\hline & Edebiyat Fakültesi & 45 & 2,18 & 1,29 & & & \\
\hline \multirow{2}{*}{ Atanma Merkezli Kaygı } & Eğitim Fakültesi & 35 & 3,20 & 1,40 & \multirow[b]{2}{*}{78} & \multirow[b]{2}{*}{,- 556} & \multirow[b]{2}{*}{, 580} \\
\hline & Edebiyat Fakültesi & 45 & 3,37 & 1,33 & & & \\
\hline \multirow{2}{*}{ Uyum Merkezli Kaygı } & Eğitim Fakültesi & 35 & 2,65 & 1,22 & \multirow[b]{2}{*}{78} & \multirow[b]{2}{*}{2,454} & \multirow[b]{2}{*}{, $016^{*}$} \\
\hline & Edebiyat Fakültesi & 45 & 2,06 & ,92 & & & \\
\hline \multirow{2}{*}{$\begin{array}{l}\text { Okul Yönetimi Merkezli } \\
\text { Kaygı }\end{array}$} & Eğitim Fakültesi & 35 & 2,65 & 1,10 & \multirow[b]{2}{*}{78} & \multirow[b]{2}{*}{, 452} & \multirow[b]{2}{*}{,652 } \\
\hline & Edebiyat Fakültesi & 45 & 2,53 & 1,14 & & & \\
\hline \multirow{2}{*}{ Genel Ortalama Kaygı } & Eğitim Fakültesi & 35 & 2,50 & ,85 & \multirow[b]{2}{*}{78} & \multirow[b]{2}{*}{, 880} & \multirow[b]{2}{*}{, 382} \\
\hline & Edebiyat Fakültesi & 45 & 2,35 & ,63 & & & \\
\hline
\end{tabular}

Tablo 12 incelendiğinde öğretmen adaylarının öğretmenlik mesleğine yönelik kaygı düzeylerinin "çok az kaygılanıyorum" ve "kısmen kaygılanıyorum" düzeyinde olduğu görülmektedir. Öğretmen adaylarının öğretmenlik mesleğine yönelik kaygı düzeylerindeki fakülte değişkenine göre oluşan farklılık sadece "uyum merkezli kaygı" boyutunda istatistiksel olarak anlamlı bulunmuştur $(\mathrm{t}(78)=2,454, \mathrm{p}<0,05)$. Bulunan bu sonuca göre öğretmen adaylarının öğretmenlik mesleğine yönelik kaygı düzeylerinde öğrenim gördükleri fakülte "uyum merkezli kaygı" boyutundaki kaygı düzeylerinde değişikliğe yol açarken diğer boyutlardaki kaygı düzeylerinde değişikliğe yol açmamaktadır.

Tablo 13

Öğretmen Adaylarının öğretmenlik mesleğine yönelik kaygllarına yönelik cinsiyete iliş̧kin $t$ testi sonuçları

\begin{tabular}{|c|c|c|c|c|c|c|c|}
\hline & Cinsiyet & $\mathbf{N}$ & $\bar{X}$ & Ss & Sd & $\mathbf{t}$ & $\mathbf{p}$ \\
\hline \multirow{2}{*}{ Görev Merkezli Kaygı } & Kadın & 35 & 2,53 & ,98 & \multirow[b]{2}{*}{78} & \multirow[b]{2}{*}{2,294} & \multirow[b]{2}{*}{, $024 *$} \\
\hline & Erkek & 45 & 2,10 & ,71 & & & \\
\hline \multirow{2}{*}{$\begin{array}{l}\text { Ekonomik/ Sosyal } \\
\text { Merkezli Kayg1 }\end{array}$} & Kadın & 35 & 2,63 & ,93 & \multirow[b]{2}{*}{78} & \multirow{2}{*}{,- 297} & \multirow[b]{2}{*}{,768 } \\
\hline & Erkek & 45 & 2,69 & ,88 & & & \\
\hline \multirow{2}{*}{$\begin{array}{l}\text { Öğrenci/ İletişim } \\
\text { Merkezli Kaygı }\end{array}$} & Kadın & 35 & 2,38 & 1,06 & \multirow[b]{2}{*}{78} & \multirow[b]{2}{*}{,765 } & \multirow[b]{2}{*}{,447 } \\
\hline & Erkek & 45 & 2,20 & ,99 & & & \\
\hline \multirow{2}{*}{$\begin{array}{l}\text { Meslektaş ve Veli } \\
\text { Merkezli Kayg1 }\end{array}$} & Kadın & 35 & 2,28 &, 88 & \multirow[b]{2}{*}{78} & \multirow[b]{2}{*}{,756 } & \multirow[b]{2}{*}{,452 } \\
\hline & Erkek & 45 & 2,12 & ,98 & & & \\
\hline \multirow{2}{*}{$\begin{array}{l}\text { Kişisel Gelişim } \\
\text { Merkezli Kayg1 }\end{array}$} & Kadın & 35 & 2,16 & 1,15 & \multirow[b]{2}{*}{78} & \multirow[b]{2}{*}{,- 290} & \multirow[b]{2}{*}{, 772} \\
\hline & Erkek & 45 & 2,24 & 1,32 & & & \\
\hline \multirow{2}{*}{ Atanma Merkezli Kaygı } & Kadın & 35 & 3,34 & 1,42 & \multirow[b]{2}{*}{78} & \multirow[b]{2}{*}{, 272} & \multirow[b]{2}{*}{,786 } \\
\hline & Erkek & 45 & 3,26 & 1,31 & & & \\
\hline
\end{tabular}




\begin{tabular}{|c|c|c|c|c|c|c|c|}
\hline \multirow{2}{*}{ Uyum Merkezli Kaygı } & Kadın & 35 & 2,43 & 1,09 & \multirow[b]{2}{*}{78} & \multirow[b]{2}{*}{, 803} & \multirow[b]{2}{*}{,425 } \\
\hline & Erkek & 45 & 2,23 & 1,11 & & & \\
\hline \multirow{2}{*}{$\begin{array}{l}\text { Okul Yönetimi Merkezli } \\
\text { Kaygı }\end{array}$} & Kadın & 35 & 2,62 & 1,16 & \multirow[b]{2}{*}{78} & \multirow[b]{2}{*}{, 251} & \multirow[b]{2}{*}{, 802} \\
\hline & Erkek & 45 & 2,56 & 1,09 & & & \\
\hline \multirow{2}{*}{ Genel Ortalama Kayg1 } & Kadın & 35 & 2,52 & ,77 & \multirow[b]{2}{*}{78} & \multirow[b]{2}{*}{1,110} & \multirow[b]{2}{*}{, 270} \\
\hline & Erkek & 45 & 2,34 & ,70 & & & \\
\hline
\end{tabular}

Tablo 13 incelendiğinde cinsiyet değişkeninin sadece öğretmen adaylarının görev merkezli kaygı düzeyinde anlamlı farklılığa yol açttğı görülmektedir $(\mathrm{t}(78)=2,294, \quad \mathrm{p}<0,05)$. Cinsiyet değişkeni öğretmen adaylarının diğer boyutlardaki kaygı düzeylerini değiştirmemektedir.

Tablo 14

Öğretmen adaylarının AGNO’larına göre ögretmenlik mesleğine yönelik kaygl düzeylerine ilişkin betimsel verileri

\begin{tabular}{|c|c|c|c|c|c|c|c|c|c|c|c|c|c|c|c|c|c|c|c|}
\hline \multirow[b]{2}{*}{ AGNO } & & \multicolumn{2}{|c|}{$\begin{array}{c}\text { Görev } \\
\text { Merkezli } \\
\text { Kayg1 }\end{array}$} & \multicolumn{2}{|c|}{\begin{tabular}{|c|} 
Ekonomik/ \\
Sosyal \\
Merkezli \\
Kayg1 \\
\end{tabular}} & \multicolumn{2}{|c|}{$\begin{array}{c}\text { Öğrenci/ } \\
\text { İletişim } \\
\text { Merkezli } \\
\text { Kayg1 }\end{array}$} & \multicolumn{2}{|c|}{$\begin{array}{c}\text { Meslektaş } \\
\text { ve Veli } \\
\text { Merkezli } \\
\text { Kaygı }\end{array}$} & \multicolumn{2}{|c|}{$\begin{array}{c}\text { Kişisel } \\
\text { Gelişim } \\
\text { Merkezli } \\
\text { Kayg1 }\end{array}$} & \multicolumn{2}{|c|}{$\begin{array}{c}\text { Atanma } \\
\text { Merkezli } \\
\text { Kaygı }\end{array}$} & \multicolumn{2}{|c|}{$\begin{array}{c}\text { Uyum } \\
\text { Merkezli } \\
\text { Kaygı }\end{array}$} & \multicolumn{2}{|c|}{$\begin{array}{c}\text { Okul } \\
\text { Yönetimi } \\
\text { Merkezli } \\
\text { Kayg1 }\end{array}$} & \multicolumn{2}{|c|}{$\begin{array}{c}\text { Genel } \\
\text { Ortalama } \\
\text { Kayg1 }\end{array}$} \\
\hline & & $\bar{X}$ & & $\bar{X}$ & Ss & $\bar{X}$ & Ss & $\bar{X}$ & Ss & $\bar{X}$ & Ss & $\bar{X}$ & & $\bar{X}$ & & $\bar{X}$ & Ss & $\bar{X}$ & Ss \\
\hline & & & & & & & & & & & & & & & & & & & 13 \\
\hline & & & & & & & & & & & & & & & & & & & \\
\hline & & & & & 77 & & & &, 85 & 16 & & & & & & 55 & & 2,38 &, 65 \\
\hline & 2 & & & 43 & 1,62 & 1,92 & 0 & & 1,41 & 87 & 1,24 & (0 & & 2,17 & & 2,17 & 5 & 2,14 & 1,4 \\
\hline OPLAM & 80 & 2,29 & & 2,67 & ,90 & 2,28 & 1,02 & 2,19 & ,94 & 2,20 & 1,24 & 3,30 & 1,35 & 2,32 & 1,10 & 2,58 & 1,12 & 2,42 &, 73 \\
\hline
\end{tabular}

Tablo 14 incelendiğinde öğretmen adaylarının AGNO’larına göre, görev merkezli kaygı düzeylerinin 3,11(2,00-2,49)- 2,25(3,50-4,00) arasında, ekonomik/ sosyal merkezli kayg1 düzeylerinin 3,93(2,00-2,49)2,43(3,50-4,00) arasında, öğrenci/ iletişim merkezli kaygı düzeylerinin 4,17(2,00-2,49)- 1,92(3,50-4,00) arasında, meslektaş ve veli merkezli kaygı düzeylerinin 3,00(2,00-2,49)- 2,00(3,50-4,00) arasında, kişisel gelişim merkezli kayg1 düzeylerinin 3,75(2,00-2,49)- 1,87(3,50-4,00) arasında, atanma merkezli kayg1 düzeylerinin 4,50(2,00-2,49)- 2,00(3,50-4,00) arasında, uyum merkezli kaygı düzeylerinin 2,83(2,00-2,49)- 2,11 (3,00-3,49) arasında, okul yönetimi merkezli kaygı düzeylerinin 3,67(2,00-2,49)- 2,17 (3,50-4,00) arasında, genel ortalama kayg1 düzeylerinin ise 3,53(2,00-2,49)- 2,14(3,50-4,00) arasında değiştiği görülmektedir. Genel anlamda bakıldığında kaygı düzeyinin en yüksek olduğu grup AGNO'ları 2,00-2,49 arasında olan öğretmen adaylarıyken, kayg1 düzeyleri en düşük olan grubun, AGNO’ları 3,50-4,00 arasında olan öğretmen adayları olduğu görülmektedir. Gruplar arasındaki farklılığın istatistiksel açıdan anlamlı olup olmadığını belirlemek için ANOVA testi yapılmış ve sonuçlar tablo 15 'de verilmişstir.

Tablo 15

Öğretmen adaylarının ögretmenlik mesleğine yönelik kaygı düzeylerinin AGNO’larına ilişkin tek yönlü ANOVA sonuçlart

\begin{tabular}{|c|c|c|c|c|c|c|}
\hline & & KT & Sd & KO & $\mathbf{F}$ & $\mathbf{p}$ \\
\hline \multirow{3}{*}{$\begin{array}{l}\text { Görev Merkezli } \\
\text { Kayg1 }\end{array}$} & AGNO & 1,369 & 3 & ,456 & \multirow[t]{3}{*}{,608 } & \multirow[t]{3}{*}{, 612} \\
\hline & Hata & 57,057 & 76 & ,751 & & \\
\hline & TOPLAM & 58,426 & 79 & & & \\
\hline \multirow{3}{*}{$\begin{array}{l}\text { Ekonomik/ } \\
\text { Sosyal Merkezli } \\
\text { Kayg1 }\end{array}$} & AGNO & 3,355 & 3 & 1,118 & \multirow[t]{3}{*}{1,403} & \multirow[t]{3}{*}{,248 } \\
\hline & Hata & 60,568 & 76 & ,797 & & \\
\hline & TOPLAM & 63,923 & 79 & & & \\
\hline \multirow{3}{*}{$\begin{array}{l}\text { Öğrenci/ İletişim } \\
\text { Merkezli Kayg1 }\end{array}$} & AGNO & 7,706 & 3 & 2,569 & \multirow[t]{3}{*}{2,622} & \multirow[t]{3}{*}{, 057} \\
\hline & Hata & 74,458 & 76 & 980 & & \\
\hline & TOPLAM & 82,164 & 79 & & & \\
\hline \multirow{3}{*}{$\begin{array}{l}\text { Meslektaş ve Vel } \\
\text { Merkezli Kaygi }\end{array}$} & $\overline{\mathrm{AGNO}}$ & 1,449 & 3 & ,483 & \multirow[t]{3}{*}{541} & \multirow[t]{3}{*}{,656 } \\
\hline & Hata & 67,823 & 76 & 892 & & \\
\hline & TOPLAM & 69,272 & 79 & & & \\
\hline \multirow{3}{*}{$\begin{array}{l}\text { Kişisel Gelişim } \\
\text { Merkezli Kayg1 }\end{array}$} & AGNO & 5,093 & 3 & 1,698 & \multirow[t]{3}{*}{1,106} & \multirow[t]{3}{*}{,352 } \\
\hline & Hata & 116,669 & 76 & 1,535 & & \\
\hline & TOPLAM & 121,762 & 79 & & & \\
\hline \multirow{3}{*}{$\begin{array}{l}\text { Atanma Merkezli } \\
\text { Kaygı }\end{array}$} & AGNO & 6,971 & 3 & 2,324 & \multirow[t]{3}{*}{1,283} & \multirow[t]{3}{*}{,286 } \\
\hline & Hata & 137,694 & 76 & 1,812 & & \\
\hline & TOPLAM & 144,665 & 79 & & & \\
\hline Uyum Merkezli & $\overline{\mathrm{AGNO}}$ & 6,536 & 3 & 2,179 & \multirow[t]{2}{*}{1,870} & \multirow[t]{2}{*}{, 142 } \\
\hline Kayg1 & $\overline{\text { Hata }}$ & 88,553 & 76 & 1,165 & & \\
\hline
\end{tabular}




\begin{tabular}{|c|c|c|c|c|c|c|}
\hline & TOPLAM & 95,089 & 79 & & & \\
\hline \multirow{3}{*}{$\begin{array}{l}\text { Okul Yönetimi } \\
\text { Merkezli Kayg1 }\end{array}$} & $\overline{\mathrm{AGNO}}$ & 2,761 & 3 & ,920 & \multirow[t]{3}{*}{, 732} & \multirow[t]{3}{*}{,536 } \\
\hline & Hata & 95,572 & 76 & 1,258 & & \\
\hline & TOPLAM & 98,333 & 79 & & & \\
\hline \multirow{3}{*}{$\begin{array}{l}\text { Genel Ortalama } \\
\text { Kaygı }\end{array}$} & AGNO & 2,719 & 3 & ,906 & \multirow[t]{3}{*}{1,754} & \multirow[t]{3}{*}{, 163 } \\
\hline & Hata & 39,276 & 76 & ,517 & & \\
\hline & TOPLAM & 41,995 & 79 & & & \\
\hline
\end{tabular}

Tablo 15 incelendiğinde öğretmen adaylarının hem genel kaygı düzeylerindeki hem de boyutlar bazında kaygı düzeylerindeki AGNO değişkenine ilişkin $\mathrm{F}$ değeri anlamlı bulunmamıştır( $\mathrm{p}>0,05)$. Bulunan bu sonuca göre öğretmen adaylarının AGNO’ları, öğretmenlik mesleğine yönelik kaygı düzeylerini değiştirmemektedir.

Tablo 16

Öğretmen adaylarının okudukları bölümü tercih etme nedenlerine göre ögrretmenlik mesleğine yönelik kaygı düzeylerine ilişkin betimsel verileri

\begin{tabular}{|c|c|c|c|c|c|c|c|c|c|c|c|c|c|c|c|c|c|c|c|}
\hline & & $\begin{array}{r}\mathrm{G} \dot{ } \\
\mathrm{Mer} \\
\mathrm{K}\end{array}$ & $\begin{array}{l}\text { rev } \\
\text { kezli } \\
\text { yg1 }\end{array}$ & $\begin{array}{r}\text { Ekon } \\
\text { Sos } \\
\text { Mer } \\
\text { Ka } \\
\end{array}$ & $\begin{array}{l}\text { nik/ } \\
\text { al } \\
\text { ezli } \\
\text { g1 }\end{array}$ & $\begin{array}{l}\text { Öğr } \\
\text { İlet } \\
\text { Mer } \\
\text { Ka }\end{array}$ & $\begin{array}{l}\text { enci/ } \\
\text { şim } \\
\text { kezli } \\
\text { yg1 }\end{array}$ & $\begin{array}{c}\text { Mes } \\
\text { ve } \\
\text { Mer } \\
\text { Ka }\end{array}$ & $\begin{array}{l}\text { ektaş } \\
\text { Veli } \\
\text { kezli } \\
\text { yg1 }\end{array}$ & $\begin{array}{r}\mathrm{Ki} \\
\mathrm{Gel} \\
\mathrm{Mer} \\
\mathrm{Ka}\end{array}$ & $\begin{array}{l}\text { isel } \\
\text { işim } \\
\text { kezli } \\
\text { yg1 }\end{array}$ & $\begin{array}{l}\text { Ats } \\
\mathrm{Me} \\
\mathrm{K}\end{array}$ & & $\begin{array}{r}\text { Uy } \\
\text { Mer } \\
\mathrm{Ka}\end{array}$ & & $\begin{array}{r}\mathrm{O} \\
\text { Yön } \\
\text { Mer } \\
\mathrm{K}\end{array}$ & $\begin{array}{l}\text { kul } \\
\text { etimi } \\
\text { kezli } \\
\text { yg1 }\end{array}$ & $\begin{array}{r}\mathrm{Ge} \\
\text { Ortal } \\
\mathrm{Ka}\end{array}$ & \\
\hline i & $\mathbf{N}$ & $\bar{X}$ & Ss & $\bar{X}$ & Ss & X & Ss & $\bar{X}$ & Ss & $\bar{X}$ & Ss & $\bar{X}$ & Ss & $\bar{X}$ & Ss & $\bar{X}$ & Ss & $\bar{X}$ & Ss \\
\hline & 15 & 2,44 & & 2,33 & ,69 & 2,12 & 1,01 & 2,25 & 1,04 & 2,07 & 1,10 & 3,67 & 1,04 & 2,67 & 1,27 & 2,31 & 1,09 & 2,42 & ,80 \\
\hline Iması & 24 &, 18 & 84 & ,85 & ,75 & 2,18 & 1,00 & 2,25 & ,97 & 2,06 & 1,22 & 2,94 & 1,36 & 2,19 & ,91 & 2,75 & 1,17 & 2,37 & ,77 \\
\hline İş gar & 6 & 38 & ,74 & 45 & ,71 & 2,61 & 1,10 & 33 & ,80 & 2,04 & 1,40 & 2,61 & 1,41 & 2,22 & 1,00 & 2,78 & 1,19 & 2,42 &, 73 \\
\hline nenlerin & 3 & 1,86 & ,40 & 3,05 & 1,43 & 2,67 & 2,02 & 1,73 & ,70 & 2,33 & 1,23 & 3,78 & 2,12 & 2,11 & 1,02 & 3,11 & 1,17 & 2,41 & ,91 \\
\hline $\begin{array}{l}\text { Anne } \\
\text { telkir } \\
\end{array}$ & 5 & 1,79 &, 40 & 3,49 & 1,06 & 2,13 & 75, & 1,92 & ,81 & 1,85 & 1,02 & 2,87 & 1,22 & 2,80 & 1,56 & 2,47 & 1,54 & 2,30 & ,65 \\
\hline $\begin{array}{l}\text { Coğrafyaya } \\
\text { karş1 olan } \\
\text { iloim }\end{array}$ & 27 & 2,43 & ,87 & 2,55 & 1,00 & 2,36 & 1,01 & 2,17 & ,97 & 2,49 & 1,38 & 3,58 & 1,39 & 2,19 & 1,12 & 2,51 & 1,03 & 2,48 & ,71 \\
\hline TOPLAM & 80 & 2,29 & ,86 & 2,67 & ,90 & 2,28 & 1,02 & 2,19 & ,94 & 2,20 & 1,24 & 3,30 & 1,35 & 2,32 & 1,10 & 2,58 & 1,12 & 2,42 & ,73 \\
\hline
\end{tabular}

Tablo 16 incelendiğinde öğretmen adaylarının okuduğu bölümü tercih etme nedenlerine göre, görev merkezli kaygı düzeylerinin 2,44(ÖSS-LYS Puanım)- 1,79(Anne-baba telkini) arasında, ekonomik/ sosyal merkezli kaygı düzeylerinin 3,49(Anne-baba telkini)- 2,33(ÖSS-LYS Puanım) arasında, öğrenci/ iletişim merkezli kaygı düzeylerinin 2,67(Öğretmenlerin önerisi)- 2,12(ÖSS-LYS Puanım) arasında, meslektaş ve veli merkezli kaygı düzeylerinin 2,33(İş garantisi)- 1,73(Öğretmenlerin önerisi) arasında, kişisel gelişim merkezli kaygı düzeylerinin 2,49(Coğrafyaya karşı olan ilgim)- 1,85(Anne-baba telkini) arasında, atanma merkezli kaygı düzeylerinin 3,78(Öğretmenlerin önerisi)- 2,61(İş garantisi) arasında, uyum merkezli kaygı düzeylerinin 2,80(Anne-baba telkini)- 2,11(Öğretmenlerin önerisi) arasında, okul yönetimi merkezli kaygı düzeylerinin 3,11(Öğretmenlerin önerisi)- 2,31(ÖSS-LYS Puanım) arasında, genel ortalama kaygı düzeylerinin ise 2,48(Coğrafyaya karşı olan ilgim)- 2,30(Anne-baba telkini) arasında değiştiği görülmektedir. Gruplar arasındaki farklılığın istatistiksel açıdan anlamlı olup olmadığını belirlemek için ANOVA testi yapılmış ve sonuçlar tablo 17 'de verilmiştir.

Tablo 17

Öğretmen adaylarının öğretmenlik mesleğine yönelik kaygı düzeylerinin okudukları bölümü tercih etme nedenlerine ilişkin tek yönlü ANOVA sonuçları

\begin{tabular}{|c|c|c|c|c|c|c|}
\hline & & KT & Sd & KO & $\mathbf{F}$ & $\mathbf{p}$ \\
\hline \multirow{3}{*}{$\begin{array}{l}\text { Görev Merkezli } \\
\text { Kaygı }\end{array}$} & Tercih Nedeni & 3,050 & 5 & ,610 & \multirow[t]{3}{*}{,815 } & \multirow[t]{3}{*}{, 543} \\
\hline & Hata & 55,376 & 74 & ,748 & & \\
\hline & TOPLAM & 58,426 & 79 & & & \\
\hline \multirow{3}{*}{$\begin{array}{l}\text { Ekonomik/ } \\
\text { Sosyal Merkezli } \\
\text { Kayg1 }\end{array}$} & Tercih Nedeni & 7,013 & 5 & 1,403 & \multirow[t]{3}{*}{1,824} & \multirow[t]{3}{*}{, 119 } \\
\hline & Hata & 56,910 & 74 & ,769 & & \\
\hline & TOPLAM & 63,923 & 79 & & & \\
\hline \multirow{3}{*}{$\begin{array}{l}\text { Öğrenci/ İletişim } \\
\text { Merkezli Kaygı }\end{array}$} & Tercih Nedeni & 1,988 & 5 & ,398 & \multirow[t]{3}{*}{,367 } & \multirow[t]{3}{*}{,870 } \\
\hline & Hata & 80,175 & 74 & 1,083 & & \\
\hline & TOPLAM & 82,164 & 79 & & & \\
\hline Meslektaş ve Vel & iTercih Nedeni & 1,270 & 5 & ,254 & ,276 & 925 \\
\hline
\end{tabular}




\begin{tabular}{|c|c|c|c|c|c|c|}
\hline \multirow[t]{2}{*}{ Merkezli Kaygı } & Hata & 68,002 & 74 & ,919 & & \\
\hline & TOPLAM & 69,272 & 79 & & & \\
\hline \multirow{3}{*}{$\begin{array}{l}\text { Kişisel Gelişim } \\
\text { Merkezli Kayg1 }\end{array}$} & Tercih Nedeni & 3,818 & 5 & ,764 & \multirow[t]{3}{*}{,479 } & \multirow[t]{3}{*}{,791 } \\
\hline & Hata & 117,944 & 74 & 1,594 & & \\
\hline & TOPLAM & 121,762 & 79 & & & \\
\hline
\end{tabular}

Tablo 18 (devamı)

Öğretmen adaylarının ögretmenlik mesleğine yönelik kaygı düzeylerinin okudukları bölümü tercih etme nedenlerine ilişkin tek yönlü ANOVA sonuçları

\begin{tabular}{|c|c|c|c|c|c|c|}
\hline & & KT & Sd & KO & $\mathbf{F}$ & $\mathbf{p}$ \\
\hline \multirow{3}{*}{$\begin{array}{l}\text { Atanma Merkezli } \\
\text { Kayg1 }\end{array}$} & Tercih Nedeni & 11,641 & 5 & 2,328 & 1,295 & 275 \\
\hline & 1 & 133,024 & 74 & 1,798 & & \\
\hline & TOPLAM & 144,665 & 79 & & & \\
\hline \multirow{3}{*}{$\begin{array}{l}\text { Uyum Merkezli } \\
\text { Kayg1 }\end{array}$} & Tercih Nedeni & 4,011 & 5 & ,802 & ,652 & ,661 \\
\hline & Hata & 91,078 & 74 & 1,231 & & \\
\hline & TOPLAM & 95,089 & 79 & & & \\
\hline \multirow{3}{*}{$\begin{array}{l}\text { Okul Yönetimi } \\
\text { Merkezli Kaygı }\end{array}$} & Tercih Nedeni & 3,070 & 5 & ,614 & ,477 & ,792 \\
\hline & Hata & 95,264 & 74 & 1,287 & & \\
\hline & $\underline{\text { TOPLAM }}$ & 98,333 & 79 & & & \\
\hline \multirow{3}{*}{$\begin{array}{l}\text { Genel Ortalama } \\
\text { Kayg1 }\end{array}$} & Tercih Nedeni & ,223 & 5 & ,045 & ,079 & ,995 \\
\hline & Hata & 41,772 & 74 & ,564 & & \\
\hline & TOPLAM & 41,995 & 79 & & & \\
\hline
\end{tabular}

Tablo 17 incelendiğinde öğretmen adaylarının hem genel kaygı düzeylerindeki hem de boyutlar bazında kaygı düzeylerindeki okuduğu bölümü tercih nedeni değişkenine iliş̧in $\mathrm{F}$ değeri anlamlı bulunmamıştır(p>0,05). Bulunan bu sonuca göre öğretmen adaylarının okudukları bölümü tercih nedenleri, öğretmenlik mesleğine yönelik kaygı düzeylerini değiştirmemektedir.

\section{TARTIŞMA, SONUÇ VE ÖNERILER}

Coğrafya öğretmen adaylarının öğretmenlik mesleğine yönelik tutum ve kaygı düzeylerini belirmek amacıyla yapılan bu çalışmada elde edilen bulgulara göre; öğretmen adaylarının öğretmenlik mesleğine yönelik olumlu tutum geliştirdikleri ve orta düzeyde kaygıya sahip oldukları tespit edilmiştir. Bazı değişkenlere göre tutum ve kaygı düzeyleri incelendiğinde elde edilen sonuçlar şu şekilde özetlenebilir;

1. Öğretmen adaylarının öğretmenlik mesleğine yönelik tutumları öğrenim gördükleri fakültelere göre değişmemektedir. Bu sonuçlar Alım ve Bekdemir (2006), Kaplan ve İpek (2002), Gürbüz ve Kişoğlu (2012) ile benzerlik göstermektedir. Ancak Arastaman (2013) ile benzeşmemektedir.

2. Öğretmen adaylarının öğretmenlik mesleğine yönelik tutumları cinsiyetlerine göre değiş̧memektedir. Bu sonuç Demirtaş, Cömert, ve Özer (2011), Özder, vd. (2010), Çapa ve Çil (2000), Varol, vd. (2014), Haciömeroğlu ve Taşkın (2010), Taşkın ve Haciömeroğlu (2010), Kahyaoğlu, Tan, ve Kaya (2013), Tunçeli (2013), Engin ve Koç (2014), Kartal ve Afacan (2012), Uğurlu ve Polat (2011), Can (2013) ile benzerlik gösterirken, Akkaya (2010), Doğan ve Çoban (2009), Kaplan ve İpek (2002), Pehlivan (2010), Çetinkaya (2009), Durmuşoğlu, Yanık, ve Akkoyunlu (2009), Sağlam (2008), Saracaloğlu (1992), Pektaş ve Kamer (2011), Bulut (2011), Terzi ve Tezci (2007), Kızıltaş, Halmatov, ve Sarıçam (2012), Bozdoğan, vd. (2007), Gökçe ve Sezer (2012), Eraslan ve Çakıcı (2011), Pehlivan (2008), Tümkaya (2011), Aydın ve Tekneci (2013), Güven ve Kaya (2013) ile farklılık göstermektedir.

3. Öğretmen adaylarının öğretmenlik mesleğine yönelik tutumları AGNO’larına göre değiş̧mektedir. Bu sonuç Kartal ve Afacan (2012) ile benzerlik göstermektedir. Öğretmen adaylarının AGNO'ları arttıkça öğretmenlik mesleğine yönelik tutum puanları ortalamaları da artmaktadır.

4. Öğretmen adaylarının öğretmenlik mesleğine yönelik tutumları bölümü tercih nedenlerine göre değişmektedir. Bu sonuç Özder, vd. (2010), Sağlam (2008), Saracaloğlu (1992), Bozdoğan, vd. (2007), Gökçe ve Sezer (2012), Tümkaya (2011), Gürbüz ve Kişoğlu (2012) ile benzerlik göstermektedir. İstediği meslek olması, öğretmenlerin telkini ve coğrafyaya karşı olan ilgisi nedeniyle bölümü tercih etmiş olan öğretmen adaylarının öğretmenlik mesleğine yönelik daha olumlu tutum geliştirdikleri görülmüştür. ÖSS-LYS puanı, iş garantisi ve anne-baba telkiniyle yani daha çok zorunluluktan dolayı bölümü tercih etmiş olan öğretmen adaylarının öğretmenlik mesleğine yönelik tutum puanı ortalamalarının daha düşük olduğu görülmüştür. Bu durum da öğretmenlik mesleğinin daha çok sevgi işi olduğunu ortaya koymaktadır. Öğretmenlik mesai kavramıyla yapılacak bir iş değil severek, kendini adayarak, özveriyle yapılabilecek bir meslektir.

5. Öğretmen adaylarını öğretmenlik mesleğine yönelik orta düzeyde kaygıya sahiptirler. Orta düzeyde kaygıya sahip olmaları onların öğretmenlik mesleğini layıkıyla icra edebileceklerinin bir emaresi olarak 
algılanabilir. Öğretmen adaylarının kaygı düzeylerin en yüksek olduğu boyut atanma merkezli kaygıdır. $\mathrm{Bu}$ durumun ortaya çıkmasında atanma bekleyen coğrafya öğretmeni adayı sayısının fazla olması ve öğretmen olarak mesleğe başlayabilmek için KPSS, ÖABT ve mülakat gibi çeşitli aşamalardan geçmelerinin gerekiyor olması etkili olabilir.

6. Öğretmen adaylarının uyum merkezli kaygı düzeylerinde fakültelere göre anlamlı farklılık tespit edilmiştir. Eğitim fakültesindeki öğretmen adaylarının uyum merkezli kaygı düzeyleri edebiyat fakültesinde öğrenim gören öğretmen adaylarına göre daha yüksektir.

7. Öğretmen adaylarının genel kaygı düzeyleri cinsiyete göre değişmemektedir. Bu sonuç Ünaldı ve Alaz (2008), Doğan ve Çoban (2009), Kafkas, Açak, Çoban, ve Karademir (2010), Saracaloğlu, Kumral, ve Kanmaz (2009), Atmaca (2013), Varol, vd. (2014), Dilmaç (2010), Dursun ve Karagün (2012) ile benzerlik gösterirken, Çubukçu ve Dönmez (2011), Aydın ve Tekneci (2013) ile farklılık göstermektedir. Ancak görev merkezli kaygı düzeylerinde cinsiyete göre anlamlı farklılık bulunmaktadır. Kadın öğretmen adaylarının görev merkezli kaygı düzeyleri erkek öğretmen adaylarına göre daha yüksektir.

8. Öğretmen adaylarının kaygı düzeyleri AGNO'larına göre değişmemektedir. Bu sonuç Dursun ve Karagün (2012) ile benzerlik gösterirken, Saracaloğlu, vd. (2009) ile farkl1lık göstermektedir.

9. Öğretmen adaylarının kaygı düzeyleri okuduğu bölümü tercih nedenlerine göre değişmemektedir.

Çalışmadan elde edilen sonuçlardan hareketle aşağıdaki öneriler geliştirilmiştir;

- Yapılan çalışmaların çalışma grubunu çoğunlukla öğretmen adayları oluşturmaktadır. Gelecekte bu konuda yapılacak olan çalışmaların mesleğini icraa eden öğretmenler üzerinde gerçekleştirilmesi literatüre katkı sağlayacaktır.

- Yapılan çalışmalarda kullanılan değişkenlere bakıldığında çoğunlukla cinsiyet değişkenin kullanıldığı görülmüştür. Gelecek çalışmalarda farklı değişkenlere yoğunlaşılması öğretmenlik mesleğine yönelik tutum ve kaygı üzerinde etkili olan diğer değişkenleri de ortaya koymak adına yararlı olacaktır.

- Öğretmen adaylarının mesleğe yönelik tutum puanlarının bölümü tercih nedenlerine göre değiştĭgi sonucuna ulaşılmıştır. Bölümü zorunluluktan değil de sevgi kaynaklı nedenlerden tercih eden öğretmen adaylarının mesleğe yönelik tutum puanları daha yüksektir. Ortaöğretimde öğrencilerin üniversite ve bölüm tercihlerinde puanlarının yettiği bölümlere değil, severek yapacakları mesleklere ilişkin bölümlere yönlendirilmeleri onların olumlu tutum geliştirdikleri meslekleri gerçekleştirmelerini sağlayacaktır.

- Öğretmen adaylarının kaygılarının en yüksek olduğu boyut atanma merkezli kaygıdır. Bunun temelinde atanmayı bekleyen öğretmen adayı sayısının fazla olması yatmaktadır. Devlet olarak ihtiyaç duyulan öğretmen sayısı gerekli hesaplamalarla belirlenip ihtiyaç doğrultusunda öğretmen yetiştirilmesi, ilerleyen süreçte bu kaygıyı azaltmak adına fayda sağlayacaktır.

\section{KAYNAKÇA}

Akkaya, N. (2010). Öğretmen adaylarının öğretmenlik mesleğine yönelik tutumlarının bazı değişkenlere göre incelenmesi. Buca Ë̆itim Fakültesi Dergisi(25), 35-42.

Alım, M., \& Bekdemir, Ü. (2006). Coğrafya öğretmeni adaylarının öğretmenlik mesleğine yönelik tutumları. Milli Ĕgitim Dergisi.

Arastaman, G. (2013). Eğitim ve fen edebiyat fakültesi öğrencilerinin öz-yeterlik inançları ve öğretmenlik mesleğine karşı tutumlarının incelenmesi. Ahi Evran Üniversitesi Kırşehir Eğitim Fakültesi Dergisi, 14(2), 205-217.

Atmaca, H. (2013). Almanca, Fransızca ve İngilizce öğretmenliği bölümlerinde okuyan öğretmen adaylarının mesleki kaygıları. Literature and History of Turkish or Turkic, 8(10), 67-76.

Aydın, A., \& Tekneci, E. (2013). Zihin engelliler öğretmenliği öğrencilerinin öğretmenlik mesleğine yönelik tutumları İle kaygı düzeyleri. Pegem Ĕ̈itim ve Ögretim Dergisi, 3(2), 1-12.

Başbay, M., Ünver, G., \& Bümen, N. T. (2009). Ortaöğretim alan öğretmenliği tezsiz yüksek lisans öğrencilerinin öğretmenlik mesleğine yönelik tutumları: boylamsal bir çalışma. Kuram ve Uygulamada Ĕ̈itim Yönetimi, 59(59), 345-366.

Bozdoğan, A. E., Aydın, D., \& Yıldırım, K. (2007). Öğretmen adaylarının öğretmenlik mesleğine ilişkin tutumları. Ahi Evran Üniversitesi Kırşsehir Ĕ̈itim Fakültesi Dergisi, 8(2), 83-97.

Bulut, D. (2011). Müzik öğretmeni adaylarının öğretmenlik mesleğine yönelik tutumları. Gazi Üniversitesi Gazi Eğitim Fakültesi Dergisi, 31(3), 651-674.

Büyüköztürk, Ş., Çakmak, E. K., Akgün, Ö. E., Karadeniz, Ş., \& Demirel, F. (2012). Bilimsel araştırma yöntemleri (Vol. 11). Ankara: Pegem Akademi.

Cabi, E., \& Yalçınalp, S. (2013). Öğretmen adaylarına yönelik mesleki kaygı ölçeği (mkö): Geçerlik ve güvenirlik çalışması. Hacettepe Üniversitesi Eğitim Fakültesi Dergisi, 44(44), 85-96. 
Can, Ş. (2013). Tezsiz yüksek lisans öğrencilerinin öğretmenlik mesleğine yönelik tutumları. Sosyal Ve Beşer Bilimler Araştırmaları Dergisi(24), 13-28.

Çapa, Y., \& Çil, N. (2000). Öğretmen adaylarının öğretmenlik mesleğine yönelik tutumlarının farklı değişkenler açısından incelenmesi. Hacettepe Üniversitesi Eğitim Fakültesi Dergisi, 18(18), 69-73.

Çetinkaya, Z. (2009). Türkçe öğretmen adaylarının öğretmenlik mesleğine ilişkin tutumlarının belirlenmesi. İlkögretim Online, 8(2), 298-305.

Çubukçu, Z., \& Dönmez, A. (2011). Öğretmen adaylarının mesleki kaygı düzeylerinin incelenmesi. Eğitimde Kuram ve Uygulama, 7(1), 3-25.

Demirtaş, H., Cömert, M., \& Özer, N. (2011). Öğretmen adaylarının özyeterlik inançları ve öğretmenlik mesleğine ilişkin tutumları. Eğitim ve Bilim, 36(159), 96-111.

Dilmaç, O. (2010). Görsel sanatlar öğretmeni adaylarının kaygı düzeylerinin çeşitli değişkenler açısından incelenmesi. Güzel Sanatlar Enstitüsü Dergisi(24), 49-65.

Doğan, T., \& Çoban, A. E. (2009). Eğitim fakültesi öğrencilerinin öğretmenlik mesleğine yönelik tutumları ile kaygı düzeyleri arasındaki ilişkinin incelenmesi. Eğitim ve Bilim, 34(153), 157-168.

Durmuşoğlu, M. C., Yanık, C., \& Akkoyunlu, B. (2009). Türk ve Azeri öğretmen adaylarının öğretmenlik mesleğine yönelik tutumları. Hacettepe Üniversitesi Ĕ̆itim Fakültesi Dergisi, 36(36), 76-86.

Dursun, S., \& Karagün, E. (2012). Öğretmen adaylarının mesleki kaygı düzeylerinin incelenmesi: Kocaeli Üniversitesi Beden Eğitimi ve Spor Yüksekokulu son sınıf öğrencileri üzerine bir araştırma. Kocaeli Üniversitesi Sosyal Bilimler Dergisi (24), 93-112.

Engin, G., \& Koç, G. Ç. (2014). Öğretmen adaylarının öğretmenlik mesleğine yönelik tutumlari (Ege Üniversitesi Eğitim Fakültesi Örneği). Türkiye Sosyal Araştırmalar Dergisi, 182(182), 153-168.

Eraslan, L., \& Çakıcı, D. (2011). Pedagojik formasyon programı öğrencilerinin öğretmenlik mesleğine yönelik tutumları. Kastamonu Ĕgitim Dergisi, 19(2), 427-438.

Gökçe, F., \& Sezer, G. O. (2012). Öğretmen adaylarının öğretmenlik mesleğine yönelik tutumları (Uludağ Üniversitesi Örneği). Uludă̆ Üniversitesi Ĕgitim Fakültesi Dergisi, 25(1), 1-23.

Gürbüz, H., \& Kişoğlu, M. (2012). Tezsiz yüksek lisans programına devam eden fen-edebiyat ve eğitim fakültesi öğrencilerinin öğretmenlik mesleğine yönelik tutumları (Atatürk Üniversitesi Örneği). Erzincan Ĕgitim Fakültesi Dergisi, 9(2), 71-83.

Güven, A., \& Kaya, R. (2013). Tarih öğretmeni adaylarının öğretmenlik mesleğine yönelik tutumları. The Journal of Academic Social Science Studies, 6(6), 549-566.

Hacıömeroğlu, G., \& Taşkın, Ç. Ş. (2010). Fen bilgisi öğretmenliği ve ortaöğretim fen ve matematik alanları (ofma) eğitimi bölümü öğretmen adaylarının öğretmenlik mesleğine ilişkin tutumları. Ahi Evran Üniversitesi Kırşehir Ĕgitim Fakültesi Dergisi, 11(1), 77-90.

Kafkas, M. E., Açak, M., Çoban, B., \& Karademir, T. (2010). Beden eğitimi öğretmen adaylarının öz yeterlik algıları ile mesleki kaygıları arasındaki ilişki. İnönü Üniversitesi Eğitim Fakültesi Dergisi, 11(2), 93111.

Kahyaoğlu, M., Tan, Ç., \& Kaya, M. (2013). İlköğretim öğretmen adaylarının öğrenme stilleri ve öğretmenlik mesleğine yönelik tutumları. Mustafa Kemal Üniversitesi Sosyal Bilimler Enstitüsü Dergisi, 10(21), 225-236.

Kaplan, A., \& İpek, A. S. (2002). Matematik öğretmenliği adaylarının öğretmenlik mesleğine yönelik tutumlarının incelenmesi. Eğitim ve Bilim, 27(125), 69-73.

Karadağ, R. (2012). Türkçe öğretmeni adaylarının öğretmenlik mesleğine ilişkin tutumları ve öğretmenlik mesleğini tercih nedenleri. E-Journal of New World Sciences Academy NWSA-Humanities, 7(2), 44-66.

Kartal, T., \& Afacan, Ö. (2012). Pedagojik formasyon eğitimi alan öğretmen adaylarının öğretmenlik mesleğine ilişkin tutumlarının incelenmesi. Mehmet Akif Ersoy Üniversitesi Ĕgitim Fakültesi Dergisi, 12(24), 7696.

Kayış, A. (2010). Güvenilirlik analizi. In Ş. Kalaycı (Ed.), SPSS uygulamalı çok değişkenli istatistik teknikleri (Vol. 5, pp. 403-419). Ankara: Asil Yayın Dağıtım Ltd. Şti.

Kızıltaş, E., Halmatov, M., \& Sarıçam, H. (2012). Okul öncesi öğretmenliği öğrencilerinin öğretmenlik mesleğine yönelik tutumları (Ağrı İbrahim Çeçen Üniversitesi Örneği). Mehmet Akif Ersoy Üniversitesi Ĕ̈itim Fakültesi Dergisi, 12(23), 173-189.

Özder, H., Konedralı, G., \& Zeki, C. P. (2010). Öğretmen adaylarının öğretmenlik mesleğine yönelik tutumlarının çeşitli değişkenler açısından incelenmesi. Kuram ve Uygulamada Egitim Yönetimi Dergisi, 16(2), 253-275.

Özkan, H. H. (2012). Öğretmenlik formasyon programındaki ögretmen adaylarının öğretmenlik mesleğine ilişkin tutumlarının incelenmesi (SDU Örneği). Ahi Evran Universitesi Kirsehir Egitim Fakultesi Dergisi (KEFAD), 13(2), 29-48.

Pehlivan, K. B. (2008). Sınıf öğretmeni adaylarının sosyo-kültürel özellikleri ve öğretmenlik mesleğine yönelik tutumları üzerine bir çalışma. Mersin Üniversitesi Ĕgitim Fakültesi Dergisi, 4(2), 151-168. 
Pehlivan, K. B. (2010). Öğretmen adaylarının öğrenme stilleri ve öğretmenlik mesleğine yönelik tutumları üzerine bir çalışma. İlköğretim Online, 9(2), 749-763.

Pektaş, M., \& Kamer, S. T. (2011). Fen bilgisi öğretmen adaylarinin öğretmenlik mesleğine yönelik tutumları. Türk Eğitim Bilimleri Dergisi, 9(4), 829-850.

Recepoğlu, E. (2013). Öğretmen adaylarının yaşam doyumları ile öğretmenlik mesleğine iliş̧kin tutumları arasındaki ilişkinin incelenmesi. Hacettepe Üniversitesi Eğitim Fakültesi Dergisi(1), 311-326.

Saban, A., Korkmaz, İ., \& Akbaşlı, S. (2004). Öğretmen adaylarının mesleki kaygıları. Eurasian Journal of Educational Research, 17, 198-208.

Sağlam, A. Ç. (2008). Müzik öğretmenliği bölümü öğrencilerinin öğretmenlik mesleğine yönelik tutumları. Yüzüncü Yll Üniversitesi Eğitim Fakültesi Dergisi, 5(1), 59-69.

Saracaloğlu, A. S. (1992). Beden eğitimi öğretmeni adaylarının mesleğe yönelik tutumları. Spor Bilimleri Dergisi, 3(1), 10-26.

Saracaloğlu, A. S., Kumral, O., \& Kanmaz, A. (2009). Ortaöğretim sosyal alanlar öğretmenliği tezsiz yüksek lisans öğrencilerinin öğretmenlik mesleğine yönelik yeterlikleri, kaygıları ve akademik güdülenme düzeyleri. Yüzüncü Yll Üniversitesi Ĕ̈itim Fakültesi Dergisi, 6(2), 38-54.

Serin, M. K., Güneş, A. M., \& Değirmenci, H. (2015). Sınıf öğretmenliği bölümü öğrencilerinin öğretmenlik mesleğine yönelik tutumları ile mesleğe yönelik kaygı düzeyleri arasındaki ilişki. Cumhuriyet International Journal of Education, 4(1), 21-34.

Taşkın, Ç. S.., \& Hacıömeroğlu, G. (2010). İlköğretim bölümü öğretmen adaylarının mesleğe yönelik tutumları: Nicel ve nitel verilere dayalı bir inceleme. İlköğretim Online, 9(3), 922-933.

Terzi, A. R., \& Tezci, E. (2007). Necatibey Eğitim Fakültesi öğrencilerinin öğretmenlik mesleğine ilişkin tutumları. Kuram ve Uygulamada Eğitim Yönetimi, 52(52), 593-614.

Tufan, E., \& Güdek, B. (2008). Müzik öğretmenliği mesleğine yönelik tutum ölçeğinin geliştirilmesi. Journal of Turkish Educational Sciences, 6(1), 25-40.

Tunçeli, H. İ. (2013). Öğretmen adaylarının iletişim becerileri ile öğretmenlik mesleğine yönelik tutumları arasındaki ilişkinin incelenmesi. Pegem Eğitim ve Öğretim Dergisi, 3(3), 51-58.

Tümkaya, S. (2011). Sınıf öğretmenliği öğrencilerinin iletişim becerileri ile öğretmenlik tutumlarının incelenmesi. Çukurova Üniversitesi Sosyal Bilimler Enstitüsü Dergisi, 20(2), 49-62.

Uğurlu, C. T., \& Polat, S. (2011). Sınıf öğretmenliği öğrencilerinin öğretmenlik mesleğine ilişkin tutumları. Cumhuriyet Üniversitesi Edebiyat Fakültesi Sosyal Bilimler Dergisi, 35(1), 68-74.

Ünaldı, Ü., \& Alaz, A. (2008). Coğrafya öğretmenliğinde okuyan öğretmen adaylarının mesleki kaygı düzeylerinin bazı değişkenler açısından incelenmesi. Selçuk Üniversitesi Ahmet Keleşoğlu Eğitim Fakültesi Dergisi, 26, 1-13.

Üstüner, M. (2006). Öğretmenlik mesleğine yönelik tutum ölçeğinin geçerlik ve güvenirlik çalışması. Kuram ve Uygulamada Ĕ̈itim Yönetimi, 45(45), 109-127.

Varol, Y., Erbaş, M., \& Ünlü, H. (2014). Beden eğitimi öğretmen adaylarının mesleki kaygı düzeylerinin öğretmenlik mesleğine yönelik tutumların yordama gücü. Ankara Üniversitesi Spor Bilimleri Fakültesi Dergisi, 2, 113-123.

Zaman, S., \& Coşkun, O. (2007). Orta öğretim öğrencilerinin coğrafya derslerine karşı tutumları üzerine bir araştırma: Erzurum Örneği. Doğu Coğrafya Dergisi, 12(17), 17-32.

\section{EXTENDED ABSTRACT}

The geography teachers needed by the Ministry of Education are being trained through two different sources. One of those groups are comprised of Geography Department graduates of Faculties of Education when the other is comprised of those who got graduated from Geography Branch of Faculties of Letters and received pedagogical formation training certificate. As a result of the literature scanning, many studies have been found regarding the attitude and concerns of teacher candidates from various branches towards the profession of teaching, however no studies have been found regarding the geography teacher candidates except for the studies carried out by Alım and Bekdemir (2006) regarding the attitudes of teacher candidates and by Ünaldı and Alaz (2008) regarding the concern levels of teacher candidates. This study is carried out for the purpose of making contribution to that field by determining the attitudes and concerns of teacher candidates from two different sources towards the profession of teaching.

In this study, the attitude and concern levels of both the teacher candidates from geography branch of faculty of letters who receive pedagogical formation certificates and the teacher candidates from geography teaching branch of faculty of education towards the profession of teaching have been tried to be revealed. Answers to the following questions have been sought within the frame of that primary purpose:

1. How are the attitude and concern levels of geography teacher candidates towards the profession of teaching? 
2. Are there significant differences in the attitude and concern levels of geography teacher candidates towards the profession of teaching depending on faculties, genders, CGPA's and their reasons for choosing their branches?

\section{Research Model}

This is a descriptive patterned research with survey model, since this study is carried out for the purpose of determining the attitude and concern levels of geography teacher candidates towards the profession of teaching. The studies intended for collecting data in order to determine certain features of a group are called as survey researches. (Büyüköztürk, Çakmak, Akgün, Karadeniz, \& Demirel, 2012)

\section{Study Group}

The study group of this research is comprised of 80 teacher candidates, being $45(56,3 \%)$ students from Kazım Karabekir Faculty of Education, Geography Education Department receiving pedagogical formation certificates in 2015-2016 academic year and 35 (43,7\%) senior students from the same faculty.

\section{Data Collection Tools}

"Attitude Scale Aimed at Profession of Teaching" developed by Üstüner (2006) and "Occupational Concern Scale Aimed at Teacher Candidates" developed by Cabi and Yalçınalp have been used for the purposes of study. Both scales are prepared in 5-Point Likert type. Üstüner (2006) has calculated the reliability coefficient of the scale as .93. In this study, the reliability coefficient of "Attitude Scale Aimed at Profession of Teaching" is found as .96. Also, Cabi and Yalçınalp (2013) have calculated the reliability coefficient of the scale they developed as .95. In this study, the reliability coefficient of "Occupational Concern Scale Aimed at Teacher Candidates" is found as .95, as well. The reliability coefficients obtained from both scales reveals that the scales are reliable according to Kayış (2010).

\section{Data Analysis}

Unpaired $t$ test has been used for determining whether the attitudes and concern levels of teacher candidates towards the profession of teaching change or not and one-way analysis of variance (ANOVA) has been used for determining whether there is a significant difference depending on their CGPA's and reasons for choosing their branches. Besides, Scheffe test has been performed in order to find the source of significant difference at the end of ANOVA test. SPSS software is used for analyses.

\section{Conclusion and Discussion}

According to the findings obtained in this study aimed at determining the attitude and concern levels of geography teacher candidates towards the profession of teaching; it is established that the teacher candidates have developed a positive attitude towards the profession of teaching and they have concerns at moderate level. When the attitude and concern levels are examined according to some variables, the results obtained can be summarized as follows;

1. The attitudes of teacher candidates towards the profession of teaching do not vary depending on the faculties they study at.

2. The attitudes of teacher candidates towards the profession of teaching do not vary depending on their genders.

3. The attitudes of teacher candidates towards the profession of teaching vary depending on their CGPA's. The attitude points of the teacher candidates towards the profession of teaching get higher as their CGPA's get higher.

4. The attitudes of teacher candidates towards the profession of teaching vary depending on their reasons for choosing their branches. It has been observed that the teacher candidates who had chosen the branch due to the profession being the desired profession, the suggestions of their teachers and their interest in geography develop more positive attitudes towards the profession of teaching. Teaching is not a profession to be practiced based on working shift concept but a profession that can be practiced by devotion and commitment.

5. The teacher candidates have a moderate level of concern towards the profession of teaching. The dimension which the teacher candidates demonstrate the highest level of concern is the assignment oriented concern. The facts such as the number of assignment pending teacher candidates being too high, being have to pass through stages such as KPSS, ÖABT and interviews in order to start practicing the profession of teaching may be effective in the occurrence of this situation. 
6. Significant difference has been observed in the compliance oriented concern levels of the teacher candidates depending on their faculties. The compliance oriented concern levels of the teacher candidates from the faculty of education are higher compared to the teacher candidates from the faculty of letters.

7. General concern levels of teacher candidates do not vary depending on genders. However, there is significant difference in duty oriented concern levels depending on genders. Duty oriented concern levels of female teacher candidates are higher compared to male teacher candidates.

8. Concern levels of teacher candidates do not vary depending on their CGPA's.

9. Concern levels of teacher candidates do not vary depending on their reasons for choosing their branches. 